 \\ Preprint \\ Cont - $710308-2$ \\ MSTER
}

\section{PRINTED-CIRCUIT STEERING COILS}

Robert T. Avery, Glen R. Lambertson, Chester D. Pike

February 1971

AEC Contract No. W-7405-eng -48
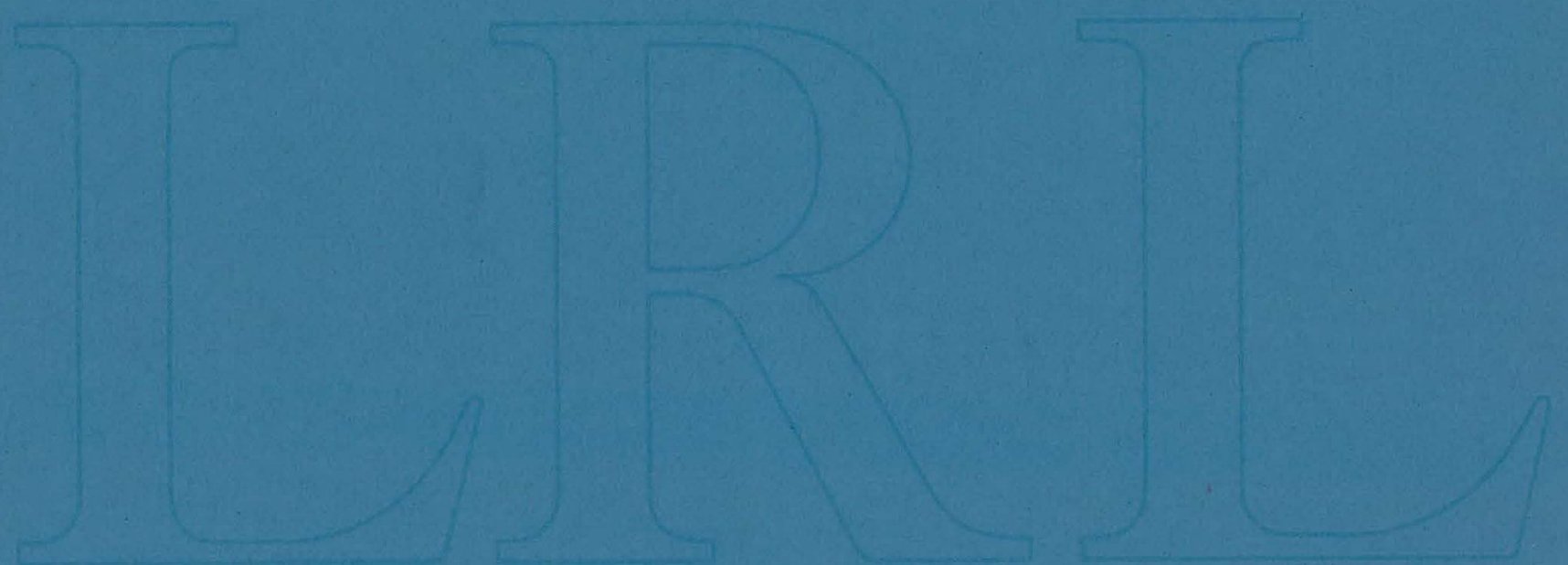

LAWRENCE RADIATION LABORATORY

UNIVERSITY of CALIFORNIA BERKELEY 


\section{DISCLAIMER}

This report was prepared as an account of work sponsored by an agency of the United States Government. Neither the United States Government nor any agency Thereof, nor any of their employees, makes any warranty, express or implied, or assumes any legal liability or responsibility for the accuracy, completeness, or usefulness of any information, apparatus, product, or process disclosed, or represents that its use would not infringe privately owned rights. Reference herein to any specific commercial product, process, or service by trade name, trademark, manufacturer, or otherwise does not necessarily constitute or imply its endorsement, recommendation, or favoring by the United States Government or any agency thereof. The views and opinions of authors expressed herein do not necessarily state or reflect those of the United States Government or any agency thereof. 


\section{DISCLAIMER}

Portions of this document may be illegible in electronic image products. Images are produced from the best available original document. 


\section{PRINTED-CIRCUIT STEERING COILS ${ }^{*}$}

Robert T. Avery, Glen R. Lambertson, Chester D. Pike

\section{Lawrence Radiation Laboratory}

University of California

Berkeley, California
This report was prepared as an account of sponsored by the United States Government. Ne the United States nor the United States Atomic En Commission, nor any of their employees, nor an their contractors, subcontractors, or their emplo makes any warranty, express or implied, or assumes legal liability or responsibility for the accuracy, pleteness or usefulness of any information, appar product or process disclosed, or represents that its would not infringe privately owned rights.

\section{Summary}

Beam steering coils utilizing "turns" etched on printed-circuit boards have been constructed and tested. This approach offers an economical method for achieving high-quality, compact steering coils. The circuit-boards are rolled into a cylinder and inserted inside a short steel tube. Boards for vertical and horizontal steering are located in separate layers. For our application, three coil sizes were constructed with inside diameters of $25 \mathrm{~cm} .20 .6 \mathrm{~cm}$, and $17.3 \mathrm{~cm}$ respectively. Active length is 0.6 of the inside diameter in all cases. The coils produce an integrated deflection field in either the vertical or horizontal direction of $~ 316$ Gauss-cm when excited with 5 A at $\sim 30 \mathrm{~V}$. The conductor pattern on the circuit-board was designed to produce a nearly uniform angular deflection for all rays transmitted, in spite of the short length/diameter ratio. The magnetic field integrated over a length of $152 \mathrm{~cm}$ was measured at several radii and azimuths. Values at 0.4 and 0.8 of bore radius were within $\sim 0.5 \%$ and $\sim 1.5 \%$ respectively of the central value. Suggestions for further refinement of deflection uniformity are presented.

\section{Conductor Pattern}

For small-angle steering in absence of iron, only currents in the beam direction contribute to net angular steering. If the current distribution on a cylindrical shell (Fig. 1) satisfies

$$
\int \frac{\partial i}{\partial \theta} d z \propto \cos \theta
$$

then steering is uniform for all rays at any $\mathrm{x}$ or $\mathrm{y}$.

The conductor patterns for the ERA $4 \mathrm{MeV}$ Injector ${ }^{1}$ steering coils, shown in Figure 2, are applied to opposite sides of a printed-circuit board. The two sides are connected series-aiding by a soldered connection through the board at the center of each "spiral". The selected rectangular conductor array has uniform pitch $p$ of the $\theta$-going contustors, is an easy pattern to lay out, and is a satisfactory choice for short $l / a$ ratio. To satisfy ( 1 ), the $z-\theta$ conductor corner follows the curve

$$
z=(\ell / 2)\left\{1 \pm 2 \sin \left[\left(90^{\circ}-\theta\right) / 2\right]\right\}
$$

The extra half-pitch length of some $z$-conductors is offset by a missing half-pitch on the reverse side of the board. "Snikes" were added at comer's to try to discourage current from shortcutting the assumed rectangular path. The theoretical integrated steering field (G-cil) of this orrangement in free space is

$$
\int_{-\infty}^{\infty} B_{y} d z=\pi I b^{2} / 20 a p
$$

If the conductors are placed inside a close-fitting iron shell of high permeability, image currents approximately double the steering strength given by $(3)$.

\section{steerlng ruil Construction}

A total of 16 steering coil assemblies of three * Work supported by the U.S. Atomic Energy Commission. different sizes have been built. The components of one assembly are shown in Figure 3. Circuit boards have .004" copper on both sides of .008" insulation laminate. Two boards are used for $\mathrm{x}$-steering and two for y-steering. 0.016" insulation sheet is used between boards. Total radial thickness of boards and insulation is .160". All boards and insulation were bonded with epoxy to provide mechanical integrity and thermal conduction to the water-cooled iron shell. The same pattern was used for all boards with photo-reduction, giving the correct circumference for each board. Principal parameters are:

$\begin{array}{lrrrr}\text { Bore I.D. } & 17.3 & 20.6 & 25.0 & \mathrm{~cm} \\ \text { Effective length, l, } & 10.5 & 12.5 & 15.1 & \mathrm{~cm} \\ \text { Iron length } & 11.4 & 13.3 & 15.9 & \mathrm{~cm} \\ \text { Resistance/circuit } & 6.0 & 6.0 & 6.0 & \Omega \\ \text { Current I (Rated) } & 5.0 & 5.0 & 5.0 & \mathrm{~A} . \\ \int_{\mathrm{y}} \mathrm{dz}, \text { calc. } & 330 & 330 & 330 & \mathrm{G}-\mathrm{cm}\end{array}$

Current of $10 \mathrm{~A}$. appears feasible, if desired. Use of the same pattern (reduced) results in equal resistance and equal integrated field for all sizes, which simplifies power supply requirements.

\section{Magnel Measurements}

Transverse magnetic fields, integrated over a length of $152 \mathrm{~cm}$, were measured. The $\int \mathrm{Bdz}$ on axis was $316 \mathrm{G}-\mathrm{cm}$ ( $96 \%$ of calculated). The field integral at $40 \%$ and $80 \%$ of bore radius deviated less than $0.5 \%$ and $1.5 \%$ respectively from the central value. The field integral was lower near the magnet poles $\left(\theta= \pm 90^{\circ}\right.$, center of spiral) and higher $90^{\circ}$ away. This fíeld quality satisfies our needs. We suspect foregoing modest errors are attributable to the current pattern at the $\mathrm{z}-\theta$ conductor corners. Improved uniformity should result from more refined study of these corner effects and/or revising the conductor spacing to compensate for the measured errors.

\section{References}

1. W. Chupp et al, "The ERA 4 MeV Injector", 1971 Particle Accelerator Cont'erence Paper G-9.

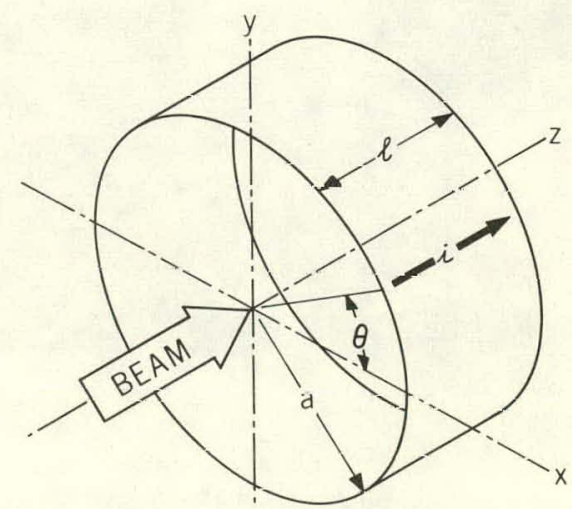

Figure 1. Steering current on cylindrical shell. 


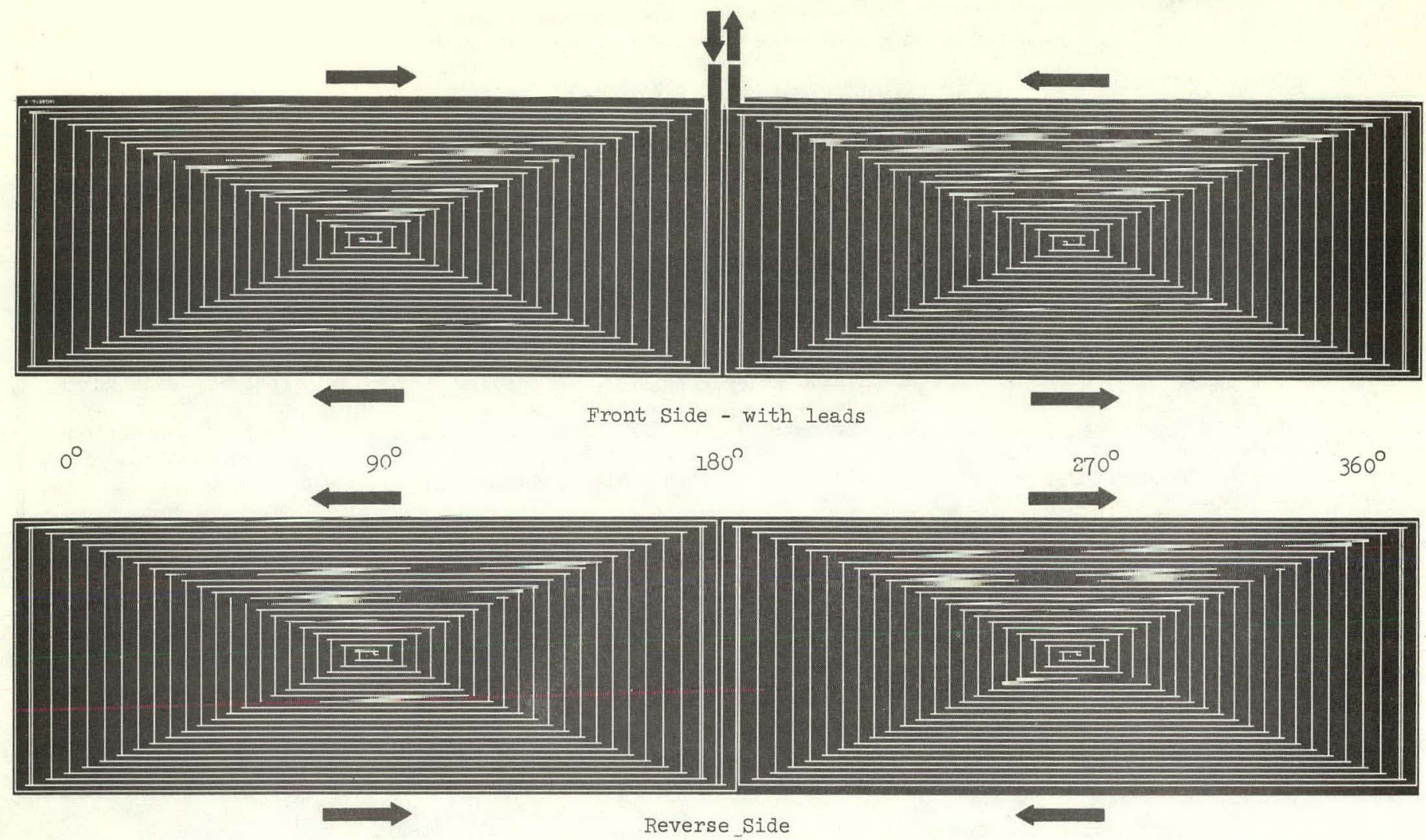

Figure 2. Conductor pattern for front and reverse sides of circuit board.

Dark areas are copper. Light areas are insulation. Arrows show direction of current flow. Solder connection through board at center of each spiral.

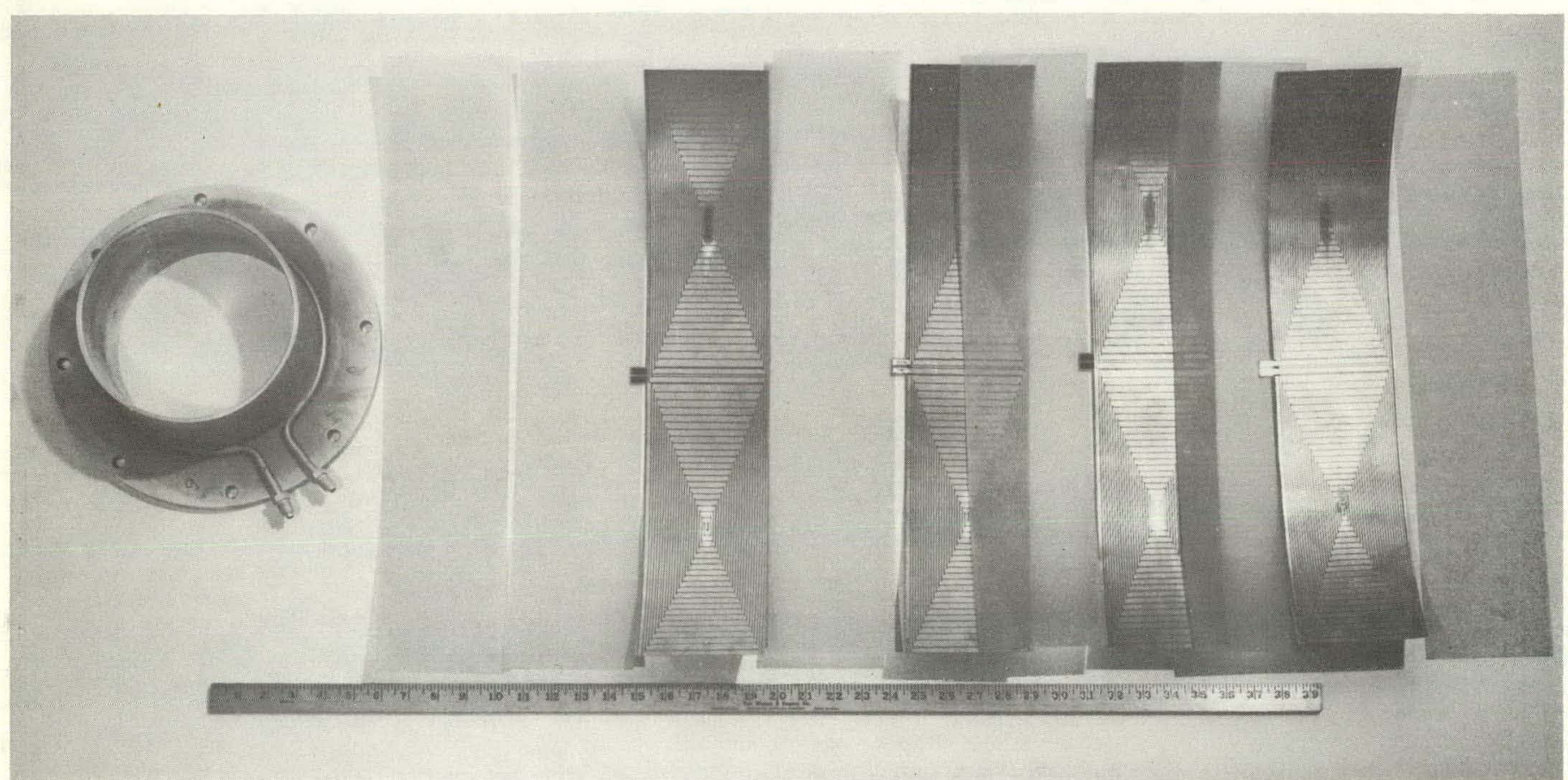

Figure 3. Component parts prior to assembly showing water-cooled iron shell, insulation sheets and printed-circuit "steering" boards. 


\section{LEGAL NOTICE}

This report was prepared as an account of work sponsored by the United States Government. Neither the United States nor the United States Atomic Energy Commission, nor any of their employees, nor any of their contractors, subcontractors, or their employees, makes any warranty, express or implied, or assumes any legal liability or responsibility for the accuracy, completeness or usefulness of any information, apparatus, product or process disclosed, or represents that its use would not infringe privately owned rights. 
